\title{
Repeat pituitary ablation for advanced prostatic cancer
}

\author{
O. Khan ${ }^{1}$, Janet Allen, G. Williams ${ }^{1}$, K. Mashiter and G.F. Joplin
}

Departments of ${ }^{l}$ Surgery/Urology and Medicine/Endocrinology, Hammersmith Hospital and Royal Postgraduate Medical School, London W12 OHS, UK.

\begin{abstract}
Summary: An elderly male patient with advanced prostatic adenocarcinoma, requiring increasing analgesia, underwent interstitial pituitary irradiation by implantation of yttrium-90. He was temporarily relieved of his pain. Assessment of his anterior pituitary function showed only a partial ablation. He therefore underwent a second implantation. This achieved complete ablation, and only when this was achieved did he experience full and sustained pain relief. We recommend assessment of anterior pituitary function in patients treated by pituitary ablation for carcinoma of the prostate, and especially in those in whom the disease progresses after initial success response.
\end{abstract}

\section{Introduction}

Between $20 \%$ and $40 \%$ of patients with painful skeletal metastases from carcinoma of the prostate will obtain complete pain relief after pituitary ablation (Ferguson \& Hendry, 1971; Thompson et al., 1974). Schoonees et al. (1972) and West \& Murphy (1973) presented evidence that total hypophyseal destruction was not necessary to achieve initial subjective (pain relief, well being and appetite) and objective (weight gain, reduction in acid and alkaline phophatase, and radiological improvement in skeletal metastases) response. We have recently had the opportunity to study a patient with advanced progressive prostatic cancer with severe skeletal pain who exemplifies the necessity for adequate endocrine assessment following attempted ablation.

\section{Case report}

A 52 year old man was diagnosed as having a poorly differentiated carcinoma of the prostate in 1957. He was treated with stilboestrol and remained in remission until 1980, when severe back pain occurred due to advancing metastases. Bilateral orchidectomy relieved his pain initially. By August 1981 he was requiring large, frequent doses of narcotic analgesia. Local radiotherapy had no effect on the pain.

In September 1981 he underwent the first ${ }^{90} \mathrm{Y}$ implantation (Joplin et al., 1978) with a dose of

Correspondence: O. Khan, F.R.C.S., Department of Surgery, Hammersmith Hospital, Royal Postgraduate Medical School, Ducane Road, London W12 0HS.

Accepted: 15 August 1984
300 kilorads at the gland surface. The pituitary fossa was radiographically normal. There was an immediate and dramatic reduction in his pain. He was discharged from hospital requiring slow release morphine sulphate at night only and hormone replacement therapy. Three months after the implant, his serum prolactin had fallen from a pre-implant level of $55 \mu \mathrm{g} / 1$ (normal range $3-15 \mu \mathrm{g} / 1$ ) to $8.5 \mu \mathrm{g} / 1$. Assessment of pituitary function at this time with a combined pituitary test using insulin, thyrotrophin releasing hormone (TRH) and luteinising hormone (LH) releasing hormone (LHRH) (Harsoulis et al., 1973) revealed only a partial ablation, as the basal cortisol was normal $(485 \mathrm{nmol} / 1$; normal range $100-500 \mathrm{nmol} / \mathrm{l}$ ) with a normal response to hypoglycaemia (glucose $1.2 \mathrm{mmol} / \mathrm{l}$, peak cortisol response $532 \mathrm{nmol} / \mathrm{l}$ ). However, there were subnormal responses of prolactin $(12.5 \mu \mathrm{g} / \mathrm{l})$, growth hormone (GH) $(5.5 \mathrm{mIU} / \mathrm{l})$, thyroid stimulatory hormone (TSH) $(4 \mathrm{mU} / \mathrm{l}), \mathrm{LH}(4 \mathrm{IU} / \mathrm{l})$ and follicle stimulating hormone (FSH) $(6 \mathrm{U} / \mathrm{l})$. Serum thyroxine remained normal. Even though only partial ablation had been achieved, he was still virtually pain-free. By 5 months his analgesia requirements increased to the same level as before the implant, and he was again chair-bound by pain.

A further implant with ${ }^{90} \mathrm{Y}$ of 300 kilorads was performed in February 1982. Post-operatively he was again rendered pain-free and required no further narcotic analgesics for the next 9 months. Assessment of pituitary function following the second implant suggested virtually complete ablation. The basal prolactin, testosterone, GH, LH, and FSH were unrecordable by radioimmunoassay, and no rise in LH or FSH occurred after LHRH. The serum thyrox- 
ine was subnormal being $54 \mathrm{nmol} / 1$ (normal range $71-148 \mathrm{nmol} / \mathrm{l})$ and intravenous TRH $(200 \mu \mathrm{g})$ resulted in no release of TSH (or prolactin). The serum cortisol was $87 \mathrm{nmol} / 1$ and steroid dependency was established clinically. A further insulin hypoglycaemia test was thus not considered necessary. Apart from steroid replacement the patient also required thyroxine and a small nightly intranasal dose of desmopressin (DDAVP) $0.05 \mathrm{ml}$, since the second procedure. Twelve months after the first implantation the patient was pain-free, mobile and in good general health, but in November 1982 there was a mild recurrence of pain, and after a very brief illness he died.

\section{Discussion}

About a third of patients undergoing pituitary ablation, either by ${ }^{90} \mathrm{Y}$ implantation or by surgical removal, are said to obtain pain relief following the procedure. Presumably this figure would significantly

\section{References}

FERGUSON, J.D. \& HENDRY, W.F. (1971). Pituitary ablation in advanced carcinoma of the prostate: analysis of 60 cases. British Journal of Urology, 43, 514.

HARSOULIS, P., MARSHALL, J.C., KUKU, S.F., BURKE, C.W., LONDON, D.R. \& FRASER, T.R. (1973). Combined test for assessment of anterior pituitary function. British Medical Journal, 4, 326.

JOPLIN, G.F., BANKS, L.M., CHILD, D.F., DIAMANT, L., DOYLE, F.H. JADRESIC, A. \& KOOCHEK, M.H. (1978). Treatment of acromegaly by pituitary implantation of ${ }^{90} \mathrm{Y}$. In Treatment of Pituitary Adenomas, Falhbusch, R. and Werder, K.v. (eds) p . 261, Georg Thieme Verlag: Stuttgart. improve if ablation was always complete, as the prognosis and survival from recurrent prostatic cancer was found to be greater after complete rather than after partial ablation (Schoonees et al., 1972). The degree of functional pituitary ablation was measured by the $\mathrm{GH}$ response to insulin induced hypoglycaemia, plasma LH, FSH, and testosterone estimation. Possibly the GH suppression is the most critical criterion (West \& Murphy, 1973). The exact mechanism by which pituitary ablation brings about this pain relief is not known, but it is apparent from the studies on our patient that while partial pituitary ablation can produce some significant degree of pain relief, a more complete ablation may be followed by a much more impressive therapeutic effect. Thus we recommend that patients with painful metastatic prostatic cancer in whom pituitary ablation is considered should have full assessment of pituitary function both before and after the ablation, as long-term success appears to depend on the completeness of the procedure.

SCHOONEES, R., BOURKE, R.S., REYNOSO, G., MURPHY G.P. \& SCHARLACH, D.S. (1972). Hypophysectomy fo reactivated disseminated prostatic carcinoma. Sou African Medical Journal, 46, 1278.

THOMPSON, J.B., GREENBERG, E., PAZIANOS, A. \& PEAR. SON, O.H. (1974). Hypophysectomy in metastatic prostatic cancer. New York State Journal Medicine, 74, 1006.

WEST, C.R. \& MURPHY, G.P. (1973). Pituitary ablation and disseminated prostatic carcinoma. Journal of the American Medical Association, 225, 253. 